\title{
NEW MOSS RECORDS FROM WESTERN PART OF TURKEY
}

\author{
Ozlem Tonguc Yayintas* \\ Biga Vocational College, Canakkale Onsekiz Mart University, 17200, Biga-Canakkale, Turkey
}

Key words: Bryophyta, Onchoporus, Sphagnum, Turkey, New records

\begin{abstract}
Two species of moss namely, Onchoporus dendrophilus Hedderson \& Blockeel and Sphagnum fimbriatum Wilson are reported for the first time from Turkey. Onchoporus dendrophilus is also a new report from Southwest Asia. Diagnostic characters, descriptions and illustrations were studied.
\end{abstract}

In Turkey, so far 760 mosses, 171 liverworts and three hornworts have been recorded (Kürschner and Frey 2011). The samples for the present research were collected as part of bryophyte research studies (2010-2012) in the Biga Peninsula located in Northwestern Turkey of Kaz Mountain area.

Kaz Mountain (1796 m), formerly known as Ida Mountain, is the highest peak of the Biga Peninsula, separating the Aegean and Marmara regions (Fig.1). The national park (39 $40^{\prime} \mathrm{N}$, $26^{\circ} 45^{\prime}$ E) consists of many deep valleys. The canyons are situated within the highlands of Kaz Mountain, and continue in a north-south direction towards the vicinity of Edremit. This region supports a diverse and distinct flora and fauna, consisting mainly of fir forests at elevations higher than $1000 \mathrm{~m}$ and pine forests at lower elevations. There are about 800 natural plant taxa in Kaz Mountain National Park and 68 of them are endemic to Turkey (Özhatay and Özhatay 2005).

Among the samples of bryophyta collections, Oncophorus dendrophilus Hedderson \& Blockeel and Sphagnum fimbriatum Wilson were identified and hitherto are reported for the first time from Turkey. The systematic enumeration of the recorded moss taxa have been provided below.

\section{Division: Bryophyta, Class: Bryopsida, Order: Dicranales, Family: Dicranaceae, Genus: Oncophorus}

1. Oncophorus dendrophilus Hedderson \& Blockeel

(Fig. 2)

(Hedderson and Blockeel 2006, 357-359, f.1)

Alar region undifferentiated, or with a few quadrate cells, somewhat enlarged and swollen basal cells $50-77.5 \mu \mathrm{m} \times(6-) 9-15 \mu \mathrm{m}$, towards costa $80 \times 20 \mu \mathrm{m}$, upper and mid-leaf cells quadrate to short rectangular, $6.5-12.5 \mu \mathrm{m} \times(5.0-) 6.0-7.5 \mu \mathrm{m}$, bistratose in the upper half, and with bistratose streaks extending $3 / 4$ of the way to leaf base; plants dark green to yellowish-green above, pale to dark brown below; capsule shape horizontal and peristome teeth reddish-orange, calyptra not seen and spores round, greenish yellow to brown.

Notes: The genus Oncophorus is represented by six species in North America, Europe and Asia. Oncophorus species may be confused with those of Dicranum, Dicranella or Kiaeria, but are distinguished by distinctively strumose capsules and abruptly subulate leaves, which are strongly crisped-contorted when dry (Allen 2000). Hedderson and Blockeel (2006) stated that in the Mediterranean area Oncophorus is largely absent and recorded only from mountain and alpine

*Author for correspondence: <ozlemyayintas@hotmail.com>. Present address: Duke University, Department of Biology, Box 90338 Durham, NC 27708, USA. 


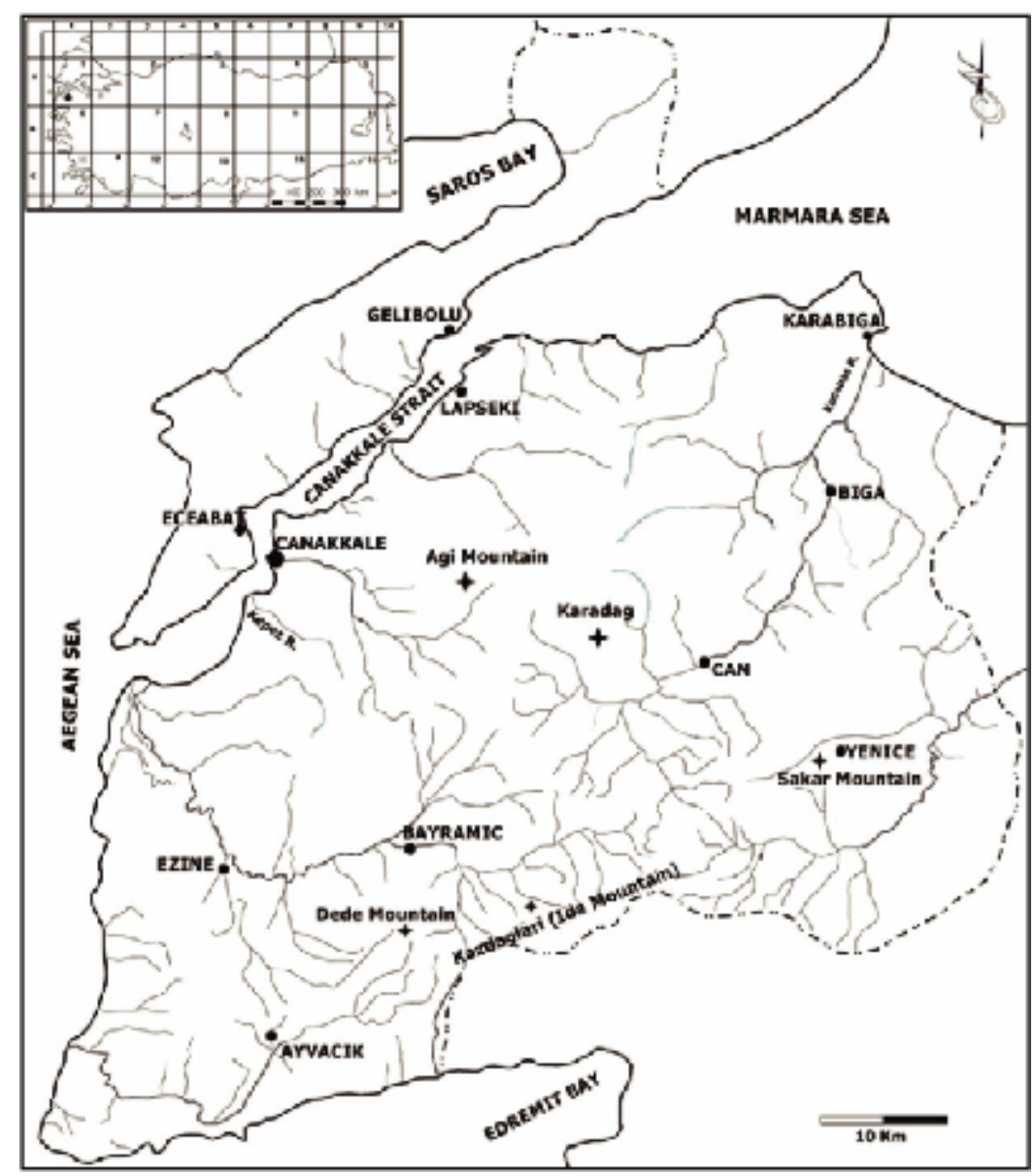

Fig. 1. Map of the study area (• district, $\bullet$ mountain).

areas of Morocco, southern Spain, Italy, Crete, Sardinia and Turkey (Frey and Kürschner 1991, Frahm et al. 1998, Ros et al. 2000, Cortini Pedrotti 2001, Rams et al. 2001). Oncophorus dendrophilus was recently described from two upland forest localities in the Cyprus, and from the White Mountains of Crete (Hedderson and Blockeel 2006). According to the checklists (Uyar and Cetin 2004, Kürschner and Erdağ 2005, Kürschner and Frey 2011) there is a one species - $O$. virens - found in the Turkey. Oncophorus dendrophilus differs from $O$. virens in having an undifferentiated alar region, or with a few quadrate cells somewhat enlarged and swollen basal cells. New to Southwest Asia and Turkey. This species was collected with Orthotrichum rupestre, Hypnum cupressiforme and Homalothecium sericeum together.

Distribution: Canakkale, Biga, Abdiağa village, nearby Abdiağa stream, inner valley, on slope, epiphytic on Platanus orientalis, 78 m, 40 $18^{\circ} 95^{\prime \prime}$ N, 27 26'15" E, 14 June, 2012, leg. O.T. Yayintas 4035. 

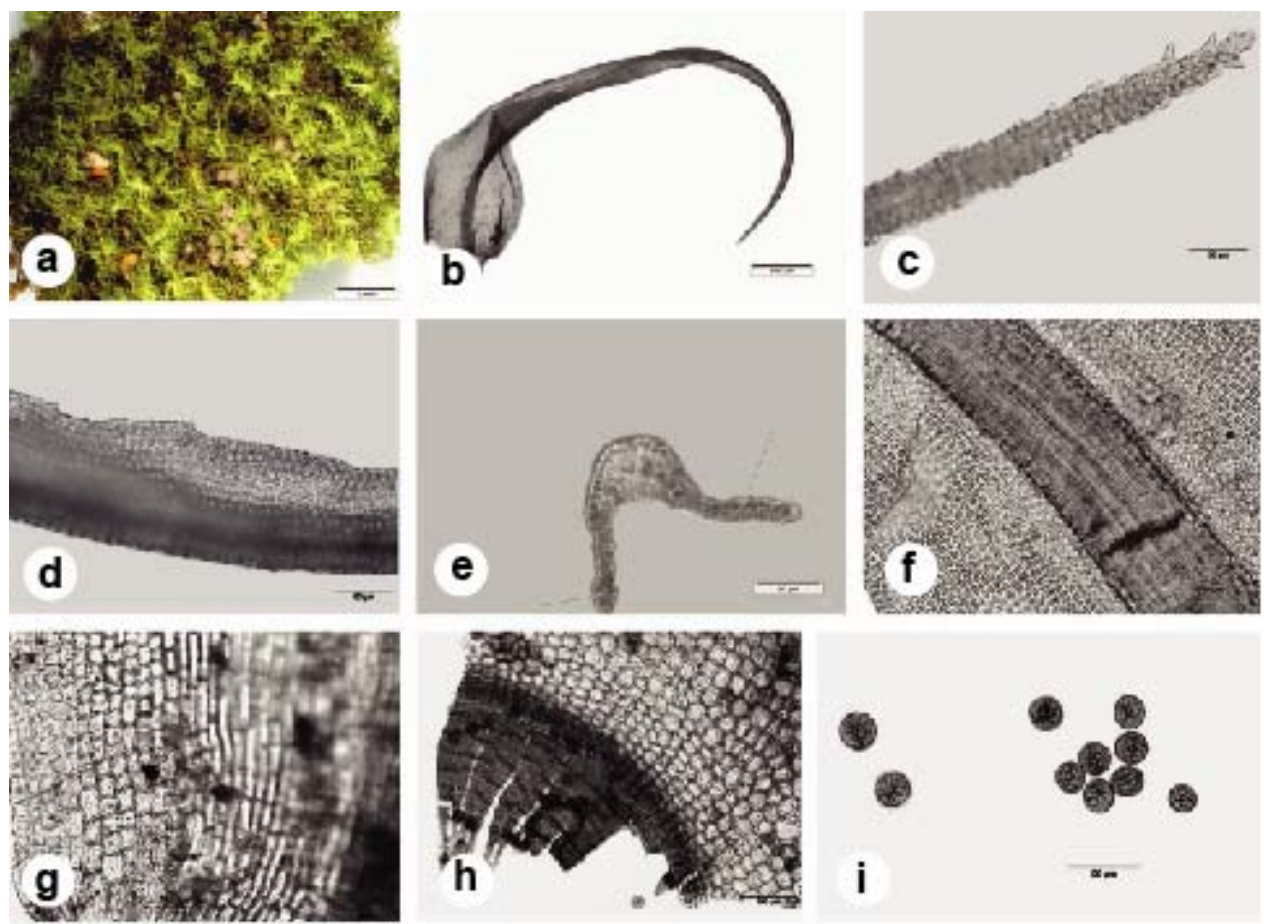

Fig. 2a-i: a-f. Oncoporus dendrophilus Hedderson \& Blockeel. a: whole plant; b: leaf; c: leaf apex; d: leaf margin nearby leaf apex; e: cross-section of leaf; f: mid-leaf cells and costa. g-i: Oncoporus dendrophilus Hedderson \& Blockeel. g: basal cells; h: peristome teeth; i: spores.

\section{Sphagnum fimbriatum Wils.}

\section{Class: Sphagnopsida, Order: Sphagnales,} Family: Sphagnaceae, Genus: Sphagnum

(Kürschner and Frey 2011, 63; Smith 2004, 61, f. 7)

Stem leaves with broad lacerate to fimbriate apex, spathulate to broad-spathulate, $0.8-1.5 \mathrm{~mm}$, has pale green to yellowish brown capitula, branch leaves ovate to ovate-lanceolate, 1.1-1.5 mm, slightly concave, straight, apex involute, margins entire, spores $24-28 \mu \mathrm{m}$, and almost smooth.

Notes: Sphagnum. fimbriatum differs from S. girgensohnii Russow by stem leaves spathulate and fimbriate whole upper part of apex. Sometimes with brown pigmentation at the basal angles.

Sphagnum fimbriatum was collected with Thuidium delicatulum, the main vascular species in Turkish peatlands. The peatland area where S. fimbriatum was collected is surrounded by a needleleaved mixed forest with Pinus nigra subsp. pallasiana, Castanea sativa, Quercus petraea, Quercus frainetto and a very limited amount of Abies nordmanniana subsp. equi-trojani (Öner 2009).

Distribution: Canakkale, Can, Söğütalan village, peat bog Ciğer gölü (Liver Lake), on a wet rocky bank, 650 m, 3952'37" N 265' $40^{\prime \prime}$ E, 16 June, 2010, leg. O.T. Yayintas 2684, det. J. Shaw. 

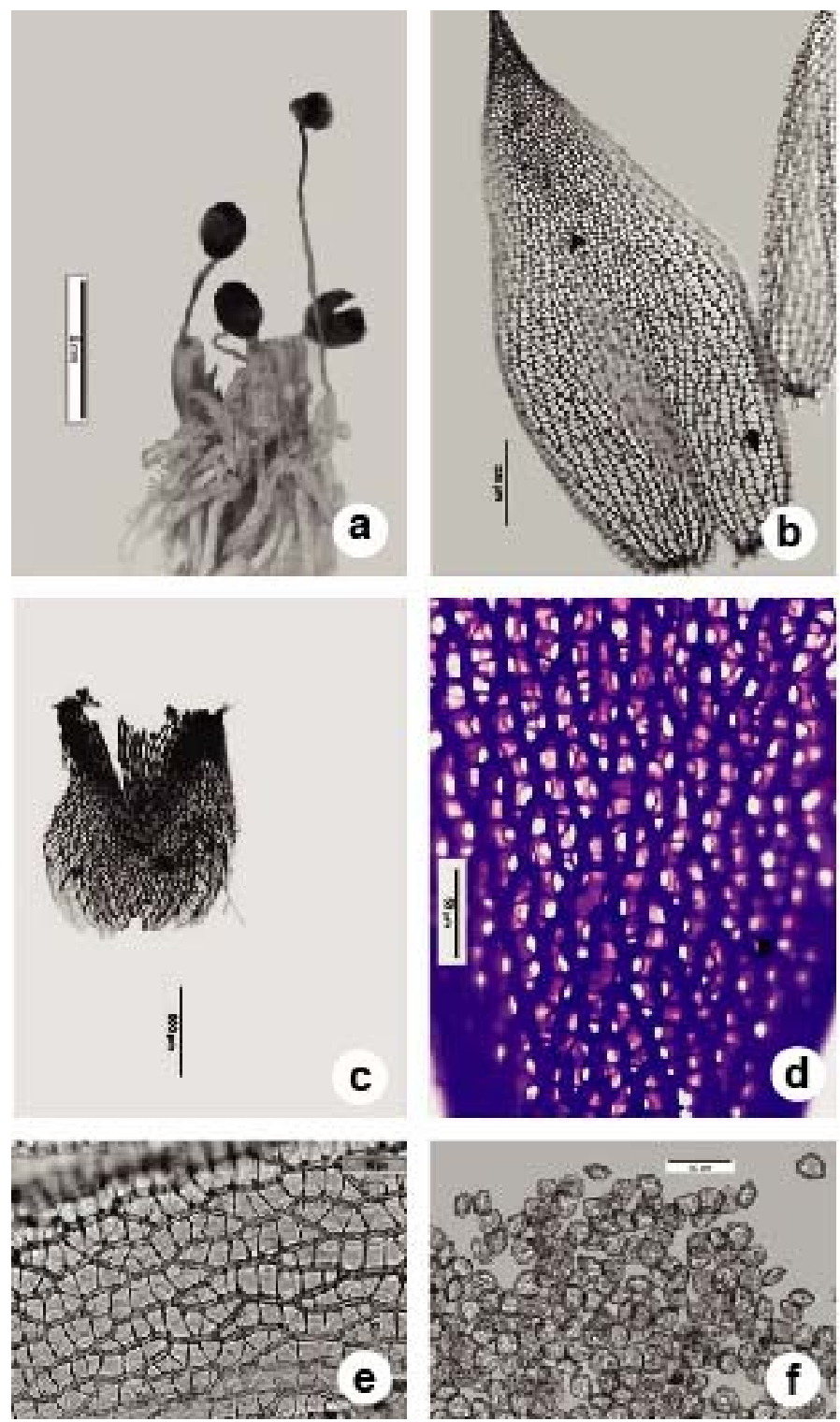

Fig. 3a-f. Sphagnum fimbriatum Wilson. a: whole plant; b: branch leaves; c: stem leaf; d: branch leaf upper cells; e: near basal cells; f: spores.

\section{Acknowledgements}

The author expresses his special thanks to Dr. A. Jonathan Shaw for confirming the identification of Sphagnum fimbriatum Wils. and making some improvement of the text. The help extended by the Curator of Duke University for using the herbarium specimens for the analogy is gratefully acknowledged. The author is thankful to the authority of Canakkale Onsekiz Mart University for granting her a sabbatical. 


\section{References}

Allen B 2000. The genus Oncophorus (Musci: Dicranaceae) in Maine. Evansia 17: 1-5.

Cortini Pedrotti C 2001. Flora Dei Muschi d'Italia, Sphagnopsida, Andreaopsida, Bryopsida (I parte), 1-817. Rome: Antonia Delfino Editore.

Frahm JP, Buchbender V, Lachmann S, Reifenrath K and Werner F 1998. Revision der Gattung Oncophorus (Musci, Dicranaceae). Trop. Bryol. 14: 119-131.

Frey W and Kürschner H 1991. Conspectus Bryophytorum Orientalum et Arabicorum. An annotated catalogue of the bryophytes of Southwest Asia. Bryophyt. Bibl. 39: 1-181.

Hedderson TA and Blockeel TL 2006. Oncophorus dendrophilus, a new moss species from Cyprus and Crete. J. Bryol. 28: 357-359.

Kürschner H and Erdag A 2005. Bryophytes of Turkey: An annotated reference list of the species with synonyms from the recent literature and an annotated list of Turkish bryological literature. Turk. J. Bot. 29: $95-154$.

Kürschner H and Frey W 2011. Liverworts, mosses and hornworts of Southwest Asia Marchantiophyta, Bryophyta, Anthocerotophyta. Nova Hedwigia 139: 1-240.

Öner S 2009. Vegetation history and human activity in $2^{\text {nd }}$ millennium AD in NW Turkey: pollen analysis in peat bog. Ann. Bot. Fennici 46: 192-200.

Özhatay N and Özhatay E 2005. Kazdağı. In: Türkiye'nin 122 Önemli Bitki Alanı (eds. Özhatay N, Byi eld A and Atay S). WWW Türkiye (Doğal Hayatı Koruma Vakfi), İstanbul, pp. 1-476.

Rams S, Ros RM, Cano MJ and Guerra J 2001. Checklist de los brio' fitos de Sierra Nevada (Andalucia, Espana). Boletin de la Sociedad Española de Briologia 18/19: 137-164.

Ros RM, Cano MJ, Muñoz J and Guerra J 2000. Contribution to the bryophyte flora of Morocco: the Jbel Toubkal. J. Bryol. 22: 283-289.

Smith AJE 2004. Moss flora of Britain and Ireland (2nd Edn) Cambridge Univ. Press. pp. 1012.

Uyar G and Çetin B (2004). A new check-list of the mosses of Turkey. J Bryol 26: 203-220.

(Manuscript received on 10 February, 2013; revised on 6 October, 2013) 